\title{
Legal Morality in Fullerian Jurisprudence
}

\section{Hemin Ibrahim Qadir}

\author{
Business Administration Department, Dukan Technical Institute, Sulaimani Polytechnic \\ University, Sulaimani, Kurdistan Region, Iraq. \\ E-mail: Hemin.qadir@spu.edu.iq
}

\author{
Najmadeen Ahmed Muhamad \\ Department of Law, College of Law, University of Sulaimani, Sulaimani, Kurdistan Region, \\ Iraq. \\ E-mail: najmarchieve@gmail.com
}

\begin{abstract}
:
The American legal philosopher Lon L. Fuller profoundly advanced a sophisticated morality conception of law through his argument for thesis of Legal Morality (LM). In particular, he adumbrated a novelist idea of " internal morality of law" that would enable the transformation of the sophisticated morality conception of law into a conception idea of law and morality connection while simultaneously providing an explanation of the new and fresh thesis of legal morality. Contrary to the common (and mostly legal positivism) view, Fuller argues that it is not only the case that the (external) morality determines what the level of any connection between law and morality, rather it is also the idea of law in itself regenerates the idea of morality (internally). However, it is argued that in spite of the fact that Fuller suggested a sophisticated account of interconnection between law and morality, he fails to develop the complexities of the (morality) connection to the law in systemic way. What does he miss in his argument of the connection between law and morality? This study will advance the view that there are more than one way to make a connection between law and morality. Some of these connections can be named here: the morality of duty, the morality of legal subject, the morality of legal official, the morality of legal end, the morality of legal content and the internal and external morality of law. This study argues that each type of these connections between law and morality importantly has many effective outcomes in term of conception and implication of law, which Fuller did not tell us. In Fuller's work, one can grasp the soundness of this connection in a variety levels. Yet, surprisingly to Fuller's own works, this study will show that Fuller's thesis of legal molarity must be expanded and justified on the different ground. In doing so, this study argues not only to make sense of Fuller's legal morality, but it also redirects the systemic way to bring all pieces of Fuller's claim of legal morality together and to seek the rationality beyond the legal.
\end{abstract}

Keywords: Philosophy of Law, Fullerian, Jurisprudence, the Connection Between Law and Morality, and Legal Morality.Orality. 


\section{Introduction:}

When the American jurist Lon L. Fuller (Muhamad-Najm, 2019:45) sets out his 1964 manifesto for The Morality of Law, after his exchange with H. L. A. Hart in the 1958 Harvard Law Review (Fuller,1955:71) he reveals that the aim of his project would respond to the "dissatisfaction with the existence literature concerning the relation between law and morality(Fuller,1964:3). He therefore takes the nature of connection between law and morality is one of his main jurisprudential inquiries. In fact, Fuller's contribution on the debate over the relation between law and morality has the long history that dated back to his early written on the legal philosophy in the 1940s(Fuller,1940:4) Although, Fuller defends the 'connection thesis' between law and morality, as the rejection of legal positivism, his ambition is always looking forward to developing the efficiency of the relation between law and morality on the model that has the direct impact on the practice of law, rather than leavening it as a mere abstraction of conceptual argument. In essence, he believes that the conversation that concerns the relation between law and morality fails to clarify "the meaning of morality itself (Fuller,1940:3) In response to this failure, Fuller significantly develops the idea that law is internally moral and has its own moral element differently from personal moral attitudes and external moral judgments toward the law. He develops this idea through the term of "the internal morality of law" as a new premise to change the direction of the debate concerning the relation between law and morality. Of special importance for the developing the internal morality of law is the appearance of other terms that attempt (but in sound puzzle) to make the connection between law and morality, such as the morality of aspiration and the morality of duty, the morality of legal contents, the morality of legal ends, and the morality of person's dignity (Barzun,2018:37).

However, Fuller's arguments for the legal morality thesis are unsound at some levels. Perhaps, one reason of this refers to his arguments are unsystematic. Several forms of connection between law and morality are overlapped in Fuller's thoughts without the justification to them. For instance, one the one hand, Fuller argues the true connection between law and morality is the "internal morality" of law, but on the other hand, Fuller does not explicitly argue why the internal morality of law considerations is not sufficient in curing the connection between law and morality, and that instead other expressions and connections have to be involved. In order to make a consistency in Fuller's arguments, we argue that Fuller's thesis of legal morality is correct and a different defense of it is offered, and in doing so we suggest that several of this connection exists and several do need further argument.

The method we adopt here is analytical and constructive. This study involves a descriptive-analytical approach; this means that we aim to describe Fuller's legal morality but believes that description cannot take place without considering the analytical aspects of this claim: that is the appeals to other forms of connection between law and morality, and unpack them in the way that explains how Fuller attempts to make a connection between law and morality. In the meantime, according to the constructive method, this study attempts to reconstruct any connection between law and morality in Fuller's thought. This approach is not only making sense of Fuller's legal morality, it also redirects the systemic way to bring all pieces of Fuller's claim of legal morality together.

The task of this study is not a review to Fuller's works. It is rather to show that Fuller's main thesis of legal morality is unsatisfactory and to advance a discourse to the thesis posed by Fuller, namely, to give a morality conception of law that enjoys multi-dimensions. But all in all, it still remains faithful to Fuller's thought, and thereby it is the study within Fullerian (not merely Fuller) jurisprudence. It should be also noticed that the novelty of this study shines once it turns to the important question of why is the thesis legal morality is important in the first place? 
The study divided into three sections. The section one argues for eight forms of connection between law and morality within Fullerian Jurisprudence in six sub-sections: first, that Fuller's idea of the morality of duty and the morality of aspiration should be expanded to how it connects with the function of law; second, that the notion of legal subject has been identified as unclear idea in Fuller's argument; third, that the morality of legal official should be reexamined; fourth, that the morality of legal ends presents the possibility of moral end of law; fifth, that moral values and substantives are part of the morality content for structuring any legal provision; and sixth, that Fuller's main idea of internal and external morality importantly (but not clearly) includes on of the above forms of relationship between law and morality, and that how these two forms overlaps through borrowing the idea of human dignity from morality into the idea of law.

Next, the section two seeks to offer the reason of why we should consider to the thesis of legal morality. The section offers three prepositions: (1) there is contingent nexus between law and morality; (2) There is necessary nexus between law and morality; and (3) there is legal practical nexus between law and morality. This shows the law depends on morality in its conception, application and implication. Finally, the section three concludes this study.

\section{The Various Relations between Law and Morality in Fullerian Jurisprudence}

This section argues that although we agree with Fuller that much attention has been paid to the question of the connection of law and morality, more partciualairy in his argument for the internal morality of law, we believe far more work needs to be done to sustain the strong claims Fuller makes for the necessary thesis of legal morality. In fact, careful review of Fuller's arguments and works shows that crucial aspects of the analysis are vulnerable to criticism and unsystematic. If our argument is to succeed, these gaps will need to be filled. For this, this section isolate eight lines of cleavage separating different forms in six sub-sections about the relationship(s) of law to morality, along line use this taxonomy to pinpoint and reflect the sense of the question of interest to us in Fullerian jurisprudence.

\section{1 The Morality of Duty and The Morality of Aspiration}

Early in The Morality of Law, Fuller addresses a key problem in modern theory of morality before the discussion of the relation between law and morals (Fuller, 1964:3-4). This is by structuring a single field of morality into two different but related areas: the morality of duty and the morality of aspirations. According to Fuller, the morality of duty, on the one hand, is elementary and began at the bottom of human conduct (Fuller, 1964:5). It lays down the basic foundations without which "an ordered society is impossible (Fuller, 1964:5). It is concerned not with utility and goals but with reciprocity and exchange (Fuller, 1964:19). The morality of aspirations, on the other hand, aims at the very top of human achievement. It is concerned with the "morality of the Good Life, of excellence, of the fullest realization of human powers (Fuller, 1964:19-22). Fuller thinks we sometimes fail to determinate the morality of aspirations because it implies some open conceptions of the highest good in human life (Fuller, 1964:5).

Fuller's structures may easily be associated with a classification of those basic ethical theories that are used according to their types of study of the genesis of morality, such as Kantianism, one the one hand, that concerns a priori - based on the principles of duty and obligation; and on the other hand, Aristotelian ethics that posteriori aims to attend those ideals, virtues and good ends of human flourishing. One obvious difference 
between these two moralities in these different traditions is in terms of the two ways of understanding the relationship between the right and the good. Kantianism typically affirms the morality of duty because to consider the actions as correct it must be independent of and on condition of one's good. Kantianism is often viewed as a part of deontological ethics (Freeman, 1995:314-345). Aristotelian ethics, on the other hand, seems paradigmatically derived from the morality of aspiration because it originated from an agency-based point of view in the idea of a well-lived and flourishing life, and then drives the notion of right or wrong from that view. Accordingly, to act correctly is to act from one's highest good (Rosalin, 1999:4). As a result, this approach can be viewed as a part of a teleological theory because it defines the right conduct as that which maximizes or produces the best state of affairs.

The argument of the above connection can be questioned by the view that despite the possibility of any differences between the two moralities in those traditions, what it important in Fuller's proposal is to think of the two moralities as a union of two halves(Fuller,1969:9) These halves can be represented, as an imaginary vertical scale(Fuller,1964:9,42) where the bottom half expresses the duty that minimizes the necessary conditions in order to avoid harm to each person when we enter in any social ordering of human interactions and reciprocity. And the top ends up as the achievement of human excellence that gives us a decent and good life (Fuller, 1969:22) consequently; one can insist there is always a continuum between the two moralities.

An important attempt is to show how the two moralities connect with the specific functions of law. Even though Fuller himself made clear that this connection was under-developed (Kristen, 2012:86), one may trace some hints in Fuller's thought (Fuller, 1975:8). In respect of law, Fuller suggests the morality of duty is something we can readily grasp; it "lays down the basic rules without which an ordered society is possible", (Fuller, 1975:15).

And thereby it more naturally resembles the foundational function of law (Fuller, 1975:5-6). It is calling on human interaction that requires the support of the ethos of the actors and participators according to the principle of reciprocity; therefore, this is the minimum a sound legal system can provide. This minimum is foundational and essential; because when they disregard the demands of this foundation the participators will be condemned "for failing to respect the basic requirements of social living."(Fuller, 1975:25) This implies then the morality of duty connects with the more foundational function of law; and this is providing people with protection and a framework, within which they can organize their relations with one another in such a manner as to make possible peaceful and profitable coexistence and human interaction (Fuller, 1975:89).

The morality of aspiration, however, is much wider to grasp, and therefore it hardly connects with the function of law. Indeed, Fuller has a doubt about how to connect between the morality of aspiration and law because the former refers to aesthetics - the artistic expression of excellence and perfection. So, speaking of human aspiration, not as minima but as excellence in the human efforts of maxima achievements, it is much more difficult to specify as well as to achieve especially in a modern and plural society. One way to comprise this connection is to say the morality of aspirations fits the purposes and policy goals of the law. Therefore it connects with the legislative or regulative function of laws that deals with the higher aims in human life, being excellence and the top of human achievement and good (Muhamad-Najm, 2019:40). In this process of realizing aspirations or ideals, the function of law is more likely instrumental in one way or another in aiming to control human behaviour to live a good life.

This entails one can speak of the relation between law and morality in Fullerian jurisprudence is referring to a relation of function premise: at the very bottom, legality sets out eight ways in which a system of law must conform to the morality of duty. At the top, legality also must conform to the morality of aspiration- an ideal standard as the guidance of law-making that the good draftsmen (Muhamad- 
Najm,2019:42) must aspire to follow if we aim to reach human flourishing in the virtue of the broader conditions of human dignity. To rephrase in Fuller's words; the idea of law as legality (the rule of law) can confront both moralities (Muhamad-Najm, 2019:9). Law as the legality, to be more precise formal legality, can be compared to a stepladder that maps out the steps in the scale, beginning from the first demands of social living of human interactions of duty up to the top of human achievements and aspirations (MuhamadNajm, 2019:20).

\section{I.2 The Morality of Legal Subject}

Legal subjects are persons who addressed by the law to conduct their behaviors and subject their actions according to the general rules. The position of legal subjects can be driven from Fuller's favorable definition of law "law is the enterprise of subjecting human conduct to the governance rules (Fuller, 1954:78). These legal subjects (persons) could be anyone who lives under the domains of law as long as that someone acts in the way, which conduct his or her actions by following, accepting, and obeying the law. Thereby, legal subjects are human beings in flesh and blood, but they should be acknowledged with the capacity of energy, agency, and personality. There is, however, a role morality that binds the legal subjects when they are recognized with capacity, agency, and dignity. This morality requires them to take the responsibility of their actions toward their fellow subjects and to fulfill their commitments in obeying the law. In return, they must be treated as moral persons who should be treated as end in themselves rather than as means and things. This way of treatment of legal subjects, in Fuller's view, is the most general aim of human life that the law must serve (Fuller, 1968:9).

The interpretation of this morality relation to law via legal personality or subjects, in Fuller's argument, may involve three main ideas.

First, Fuller presents the morality of legal subjects in the notion of citizen. Being a citizen means feeling and behaving as someone who belongs to the legal system. Perhaps the idea of the citizen can be driven from Fuller's thought on the morality of aspiration. Following Greek philosophy, Fuller believes that the morality of aspiration grants person "as a political animal [citizen] had to find the good life in a life shared other (Fuller, 1968:92-95)". Here, unlike Judge Holmes, Fuller argues that there is a room to look at the law from the perspective of a good citizen rather than from the view of a bad citizen or a bad man (Fuller, 1949:698).

In this way, the idea of the citizen reveals the role morality. This role binds legal subjects- as conscious persons who consider themselves as the subjects of law in the way they obey the law faithfully. They have faith in the law for two reasons. Firstly, they think that there is something good and valuable in the law itself, as long as, the law is capable to serve the public form of interaction among all subjects of law. The core of goodness of the law thus rests on the promise condition that preserves the stability of shared life among people. Fuller also argues that people believe in the law because they cannot live and work together without organizing some forms of bounders (such as rule, principle, system, and order) that provide them to resolve their conflicts and to promote their cooperative action (Fuller,1949:694). In this way, the law should represent the idea of the rules of law to the extent that the law protects citizens against the arbitrary exercise of power over their action by whoever exercises this power. This restriction on the power, however, must be recourse against any form of power either a government power over those who governed as citizens, or a societal power by which a group, or even one person, outside of government exercises over other citizens. Secondly, citizens concern the law as something intelligible and rational, which provides them with enough reasons to follow it. This is 
why the investigation and the observation of the rationality of the laws become the priority task for those citizens who test their obligation of fidelity to law (Fuller, 1949:41). In this way, both the faith in law and the fidelity to law complete each other (Fuller, 1949:632).

Fuller explores the implication of this task through the familiar story of King Rex and his failures to make the law to his subjects (Fuller, 1949, 650). In King Rex's project of establishing the system of rules, Rex's subjects curiously were questioning the rationality of each single step of Rex's project until the King recognized how he was wrong in his project. Nevertheless Rex's subjects were faithful to the power of their King, they had not had any faith in their King's project of law. The main reason of this failure was that in spite of taking eight routes, Rex failed to create and maintain the law in the condition that provides the 'rational ground' for asserting his citizens to obey it (Fuller, 1949:34-38). One lesson from the story is that when good citizens examine the rules of the lawmaking, they act the morality role. They are functioning as someone with faith who seeks for the real reasons to obey the legal rules. Because they have faith in the law as something that should be acceptable and intelligible to human affairs, the motive of their questioning to the lawgiver's procedures stems from the same faith (Bennett, 2011, 78).

Second, the idea of a responsible agent (Fuller, 1949:162), or a responsible person, is another way to approach the role morality of legal subjects in Fuller's argument. This idea elucidates the morality function of legal subjects through the doctrine of personal responsibility. It precisely justifies the doctrine of personal responsibility by treating legal subjects, as someone free, responsible and center of the action. The moral duty holds the legal subject the consequences of her actions and interactions as a responsible person in the realm of legal activity. In another words, the idea of a responsible person determines the legal judgment of whether to punish someone for a crime or rectify her civil wrongs and civil liability (Fuller, 1949:77). But this obligation should be seen as arising from the perspective of a person who is deciding what to do rather what should act upon her. Thus, the justification of legal judgment rests only on the treatment of legal subjects as the moral agent rather than a mere agent who might be used as someone who acts upon her (Fuller, 1949:163). For the same reason, once the idea of responsible person disappears in any branch of law, whether a private law or public law, we lose to know what justice the legal punishment, and over whom the legal punishment should be applied (Fuller, 1949:167).

Third and last, the morality of legal subject refers to the normativity and morality element within the nature of law. On the other hand, the human capacity of agency demands valuing the legal subjects qua agency and personality for their own sake, and never to be used as a mere means to an end or a purpose of the other. Unlike things, persons should not have a derivative value, and should never be used as means to some person's ends, including the lawgiver's ends. Certainly, if something along these lines is correct, it is acceptable to think that only human beings can have a special value that worth their capacity. This value should be the value of human dignity. Although Fuller does not explicitly advance this thesis, he argues against any claim that attempts to treat person as a thing not as moral agent. That is why he rejects positivism claim that presents the law as "one-way project of authority orientating with government and imposing itself upon the citizen [legal subject] (Fuller, 1949:207)". At the same time, Fuller argues that legal subjects should be always informed with legal information in the advance to the extent that they know where they stand under the demand of the law (Fuller, 1949:213-217). Hence, legal subjects via their personal humanity require a special treatment that fits their agency and dignity. 


\section{I.3 The Morality of Legal Official}

The argument of this legal morality states that the morality role of legal official within the framework of any legal system. Here, two possible conceptions of legal official in Fuller's account can be presented: the broad and the narrow conceptions. Both conceptions of legal official share the view that the legal officials should: (i) see themselves as the legal members within the legal system (ii) contribute in creating and in administrating the system of general rules (iii) constraint their law-jobs under the idea of 'role morality' to keep the law's integrity in virtue of the maintain of human interactions, the general rules, the rule of law, and the fidelity of law. Both conceptions of legal official, however, differ in the scope of membership and the degree of morality performance referring to the law.

This form of legal morality can be questioned and tested along two paths. The first one consists of the broad conception of legal officials. This conception includes all members of legal institutions, for examples, legislators, judges, lawyers, attorneys, policemen, law professors and even the law students. These members belong to the law's community, and its process, in the way that they live and act lawyering. Such a membership elucidates the working days of legal officials and their professional lives under the umbrella of law. Sometimes, the lawyers apparently are the chosen group among these members of legal official in Fuller's view. He describes the lawyers as "the architects of social structure (Fuller, 1958:13)". He even argues that the task of legal philosophers should be viewed as the direction of their fellow lawyers to decide how the lawyers may best spend their professional lives (Fuller, 1958:4).

Yet, Fuller argues each legal official member has a moral role that is based on his or her legal responsibility and professional performance. More typically, this role morality is the moral restrictions and codes of behaviors of institutional performance that lead the conducts of legal officials toward more efficiency and accuracy. The lawyers, for example, are subject to a code of ethics governing their conducts tow ard clients, fellow lawyers, courts and the public. This code sets forth special criteria to discharge of a distinctive social function of the lawyers (Fuller, 1949:193). Meantime, the core of any ethical code like this must promote the morality task of lawyers, which is "to find ways by people can live, and work together successfully (Fuller, 1949:694)".

The second path refers to the narrow conception of the legal official. When it comes to the narrow conception of legal official, Fuller exclusively addresses the lawgiver's point of view. The lawgiver as legislator or ruler should regard as occupying a distinctive and limit role that could be called a 'role morality' (Fuller, 1949:193). This morality is an actual duty that attaches to the performance of lawgiver as someone who is in the chain of command and office (Fuller, 1949:64). In adopting this perspective, Fuller attempts to attack the common view that ignores the morality duties of lawgiver that submit to his official performance. He argues despite the fact that this common view, which is a one-way project of positivism authority (Fuller, 1949:192-193), might be recognized some external requirements or constitutional restrictions over the authority of lawgiver; this view always remains short. One reason is that one way project of positivism denies the morality of official that determinates by the most important function of the job of lawgivers in making and administrating the laws (Coyle, 2014:45).

Furthermore, Fuller argues that there is a moral duty over the lawgiver that stems from the job of the law itself. This is because the lawgiver is the most important member among the legal officials who, with plans and projects, can make the achievement of law's job attainable. Thus, lawmaking implies the moral task over the office of lawgiver in the light of job of law. But what is the job of law that commits the lawgiver to the moral duties? According to Fuller, the integrity of the law is the main job of law that commits the morality duty over the lawgiver functions. The integrity of law demands the lawgiver to keep the coherency 
and efficiency of law both as the idea and as the process (Soosay,2011,32).The law's integrity as an idea first reflects the moral foundation of law, which presents the law as the framework for facilitating human interaction. Here, the morality of lawgiver becomes the philosophical viewpoint to reflect the nature of law. This view basically represents the law as the collaborative enterprise that; (i) reflects the shared values and common needs of human interaction in any society rather than specific ends set by the lawgiver; (ii) guideposts a person how to live with her fellow persons in their everyday interactions; (iii) allows a person to persuade her ends and agenda of her life; and (iv) identifies the role of government or official generally, and the lawgiver specifically as a part of this collaborative enterprise.

Then, the processes of law's integrity express the view that represents the law as the interactional process and social reality. In the first place, the lawgiver should keep the echo of law in the term of practical condition that promotes the interaction foundation of law. In Fuller's view, this practical condition of interaction manifests in the art of legality or the rule of law, whilst it sets a procedure in two levels: horizontal and vertical (Fuller, 1949:223).

Horizontally, the interactional process should set between those persons who are pursuing their own ends and their fellow persons in society. Making the balance between the two individual and society is the task of law as a social order. For this reason, the law must always "regard as a facility enabling [persons] to live a satisfactory life in common (Fuller, 1949:223)". But if this facility is to serve its intended beneficiaries, they must use and design well by those who have the responsibility to design it. This is because there is always the possibility of conflicts and tensions between the self-project of persons and the boundary of society. Here the designer is, of course, the lawgiver. From this, the morality of lawgiver is the chain of government and a guardian of the function of legal system who must provide "a citizenry with a sound and a stable framework for their interaction with one another" under the integrate system of the law More particularly, the morality of lawgiver is to plan to the fidelity of the rule of law for any private interactions among people (Fuller, 1949:210). Arguably, this morality demands also the lawgiver to respect the most basic value among people that keeps them with the capacity of action and interactions in their personal and private interactions. This value, in or view, should be human dignity.

On the vertical level, however, the interactional process of law formulates the public relationship between rulers and ruled: the lawgiver and subjects. Although this relationship rests on the silent contract between the lawgiver and subjects through the 'role expectations', the role of the lawgiver is more complex and important one. This is because the lawgiver has a commitment to spell out in what form this commitment should manifest itself (Fuller, 194:642). Basically, the practical task of this form, in Fuller's view, rests in the art of legality or the rule of law, whilst the generality of the rule characterizes the form of this public interaction. So when the lawgiver enacts the general rules, the lawgiver says to "the citizens, these are the rules we ask you to follow, if you will obey them, you have our promise that they are the rules we will apply to your conduct." Fuller argues the way that lawgiver represents the law to the legal subjects should contain the 'trusteeship' that interlocks the role expectations between the lawgiver and his subjects (Fuller, 1949:217).

This is because of two reasons. Firstly, the way in which the lawgiver represents the law to subjects shows that the lawgiver invites legal subjects' acceptance to the laws. In fact, it is implicit here that the lawgiver respects a person with agency and dignity who needs a reason to accept any laws. The reason behind this is the lawgiver represents the law as a rational thing which enables to invite a person to accept it. Therefore, it is the moral duty of lawgiver to anticipate that the citizenry as a whole will accept as law and generally observe the body of rules he has promulgated (Fuller, 1969:24). Secondly, this way secures the role of legal subjects to obey the law. Once subjects know in advance that in dealing with their lawmakers and governments will pay attention to their own declared rules, the subjects motivate to abide by those rules. The 
generality of law thus carries with it the social meaning that the lawgivers will them abides by their own rules (Fuller, 1969:217). It even recalls the meaning of democracy in a modern society when "the same citizen may be both lawgiver and legal subject (Fuller, 1969:217)". Fuller warns us of "a gross failure in the realization of either of these anticipations of government toward citizen or citizen toward government" which "can have the result that the most carefully drafted code will fail to become a functioning system of law Thus, at a vertical level, the role morality of lawgivers is to secure the integrity of law by restricting their conduct to the same enterprise of subjecting human conduct to the governance of rules (Fuller, 1969:217)". This is by setting out the form of law in the general rules that build up and maintain the trusteeship between the lawgivers and subjects.

It follows then that while the term legal official is a stretch in Fuller's account, the legal official holds to be having a role morality. The statement of this morality is more obvious, even more basis, in the case of lawgiver or ruler because of the fundamental function that attaches to the lawgiver office. The moral duty of lawgivers basically refers to their official performance and moral obligation. They have to keep the idea of the integrity of law in its more practical condition and effective form that promote the moral foundation of legal order and facilitate the human interactions in the both levels of private and public interactions (Hack and Robert, 2006:65).

\section{I.4 The Morality of Legal End}

Fuller argues as long as the law is a part of human activity and a purposeful enterprise of social reality, then the law should serve a variety of substantive ends and morally goods in a given society (Fuller, 1956:677). According to Fuller, law is not a fiat or fabric of power comes from nowhere or only from the power of ruler, it rather reflects shared values or proposes and 'common needs' of society (Fuller, 1949: 694-700). Nevertheless Fuller emphasizes that the law's aims should openly leave to serve a variety of moral ends because this matter involves the matter of teleology and the complex relation of mean-end (Fuller, 1949:146147). Specifically, he considers several legal ends in two different ways. Firstly, he identifies "subjecting human conduct to the guidance and control of general rules" as the only and the modest aim of law when he responses to the skeptics about the law as a purposeful enterprise. Secondly, he discusses several moral ends of law to show the connection between law and morality, more particularly to explain the coherency and connection between the internal morality of law and external morality of law (Fuller, 1981:48).

On the way of recognizing some moral ends as the legal ends, two points are particularly important. Firstly, the sense that law and morality are interconnected through the morality of legal ends is driven from the influences that the morality and its moral entity has on law. According to this view, these impacts appear by employing the moral values as the 'objective ends' of 'legislation of morals'. Although these moral ends could play a role of a 'critical', 'reform' and developing' of the legal rules, they remain an external morality to the law and never becomes an essential to the nature of law (Fuller, 1949:146). Second, while the moral ends of law concern the moral substance or the morality value of law, the quality of these values as legal ends depends fundamentally on the efficiency and the morality of law itself. This is because these legal moral values are only possible to account for the ends of law after they passed the task of the morality of law itself. Therefore, these moral values of law, in Fuller's view, are the product ends or states of affairs to the law that produces as the legal ends by the law and its processes, rather than a precondition of law (Rundle, 2009:28). 


\section{I.5 The Morality of Legal Content}

The argument for another type of connection between law and morality in Fullerain jurisprudence runs as follows: there is a contingent relation between the legal rules and morals, which can be named "the morality of legal content." One possible way of this connection might be addressed under the problem of 'legislating morals'. That is the practice of morals rules in the practice of legal rules. Yet Fuller seems is less interesting in this way of the morality of legal content (Fuller,1949:217).

Fuller's argument of this connection comes in the context of a fine argument with Hart's version of 'minimum content' (Hart, H.L.A, 1994:193-200). Two points can be asserted. Firstly, the matter of minimum content should be addressed under the morality of aspiration that necessarily relates to 'human aspiration'. Secondly, the idea that to support the principle of human aspiration, it should be considered that the minimum content of substantive natural law would find it in the injections: "Open up, maintain, and preserve the integrity of the channel of communication by which men [persons] convey to one another what they perceive, feel, and desire." Hence, the simple truism that Fuller sets forth in the matter of content connection between law and morals, is the human's capacity to interact and communicate with his fellows because the "communication is something more than a means of staying alive. It is a way of being alive" as puts by Fuller. He even adds a further reason when he says "it is through communication that we inherent the achievements of past human effort (Fuller, 1949:220).

\section{I.6 The "Internal" and "External" Morality of Law}

Within Fuller's argument, the distinction between the internal and external moralities of law is the most important division where the above forms of connections between law and morality may be concerned. Both moralities share the view that there must be a legal moral value, but they differ in choosing the quality of the moral value from the above connections between law and morality (Fuller, 1949:255).

One the one hand, the internal morality of law, as Fuller advocates it, maintains that there is a morality stems from the law itself. The quality of the 'morality' in the internal morality of law depends on interplay or interaction of the morality of legal officials and the morality of legal subjects. Among the legal officials, the morality role of lawgiver is an affirmative duty that requires respecting the legal subject with a practical and moral identity. This respect enables legal subject to interact with his fellows according to the law. The morality of lawgiver, thus, has the commitment to keep the system of law in its practical condition and its integrated form, namely legality, in order to provide the legal guideposts by which legal subjects coordinate their actions and follow the legal rules (Fuller, 1949:238). In the meantime, the morality role of legal subject, as 'responsible agent', is the duty of respecting his fellows in according to the public interaction that formulates in the law. Hence, the direct morality of legal subject translates to the commitment of accepting, following and obeying the legal rules that exist and administrate by the lawgiver and other legal officials in the cause of promoting the public interaction. Altogether these 'reciprocity of expectation' between the morality roles of lawgiver and subject, according to Fuller, is the moral foundation of legal order that makes the law possible Furthermore, the functioning of legal system, as Fuller observes, depends upon a cooperative effort and a responsible interaction between lawgiver and subject. The internal morality of law thus takes the morality of legal subject and the morality of legal official reframes the connections of law and morality as priority concern in demonstrating the morality quality of moral value within the law (Fuller, 1949:219). 
The argument of Fuller's internal morality can be reframed as follows: Fuller's argument can be broken down into two main stages or premises: (a) compliance with the eight principles of legality or the rule of law (that is law must be general rules, published, prospective, clear, non-contradictory, possible, stable and congruence between official action and the declared rules. is internal in the idea of law; (b) these eight principles of legality imbue law with moral value: "internal morality". Therefore, there is a necessary connection between law and morality- legal morality. The main reason for this connection between law and formal legality also relates to Fuller's consideration of law as a purposive or functional concept (Fuller, 1949:268). Law, Fuller tells us, cannot be seen as "an amoral datum to be described in the same way that one describes a stone; scientifically, pointing only to certain facts of texts, official behaviour, or state power." Law rather should be understood as "the enterprise of subjecting human conduct to the governance of rules." Certainly, governance of people can be achieved without the rule of law. The rulers, for example, can merely frighten people by enforcing them to obey the rules, or the ruled can be faithful to the ruler. The rulers could achieve their goals without conforming to formal legality in these circumstances, but these forms of governance will be without the real form of law (Jeremy, 2008:17-19). The King Rex's subjects, for example, would be remained faithful to his crown throughout his long term of governing his realm. However, people, as legal subjects, were not faithful to his rules because he never made any form of governing that could be considered as law (David, 2010:19). As Fuller concluded, such a system would not be a system of law, for conduct within the system could not be guided by general rules. In other words, such a system that is not guiding human behaviour through the rule of law, the morality that bring the moral role of legal subjects and legal officials together, has intuitive merit because that system would not qualify as a government subject to the rule of law (David, 2010:19). It follows then for something to qualify as a law that is able to guide human conduct and an institution that functions as a legal system; it must conform to the eight requirements of Fuller's legality. Adhering to the eight principles is a condition of the existence of law and the legal system that binds legal officials and legal subjects alike (David, 2010:19).

On the other hand, Fuller defines the external morality of law as another way to show the relation between law and morality. It is 'external' morality to the law because (i) the moral values in the external morality of law are allocated as the 'objects of legislation' that serve as purposes or ends of legal rules, and, (ii) the nature of these of moral values belong to the category of the morality of right, culturally conditioned and personal judgments that exclude from the domain of law. Form this; it appears that the quality of 'morality' in external morality of law lies on the third and fourth connections of law and morality. The morality of legal ends normally becomes the moral aims that the law should serve. In the meantime, the morality of legal content should be considered as the precondition morality that the law should be also recognized and protected (David, 2010:25).

With this connection in place, Fuller argues the nature of the relationship between law and these external morals might be considered as a necessary connection between law and morality, even though it does not determinate any essential contribution to the nature or concept of law. The potential necessary of this connection, as Fuller obverses, might "guide legislation, furnish standards for the criticism of existing law, and properly be taken into account in the interpretation of law." But its effective is limited on the function and nature of law. Hence, Fuller has considered the external morality of law at a lower level of consideration compering to the internal morality of law because the limitation role of earlier morality in a functioning of legal order (Fuller, 1949:645).

Although Fuller asserts on the distinction between the internal and external moralities of law, it seems the purpose of this distinction remains as a mere method of analysis, rather than a suitable tool for the exercise of judgment in practice. Accordingly, one can observes an avenue of interaction and overlap between the two 
moralities of law. In that avenue, one may argue that both moralities interacts and overlaps, they even reciprocity influence one another in a real life (Fuller, 1949:645). The course of this interaction between the two moralities of law can be highlighted in two ways.

The first way of interaction between the two moralities of law is apt in Fuller's faith on the basis that there is an infuse relations between 'coherence and goodness' in human activity, including the law (Fuller, 1949:636). He adds further: "when men are compelled to explain and justify their decisions, the effect will generally be to pull those decisions toward goodness, by whatever standards of ultimate goodness there are." This means that order, coherence, and clarity have an affinity more with goodness and moral behavior, rather than with evil purposes. To put it differently, the respect of internal morality of law, as the morality that keeps law's integrity and coherency, is likely to (i) avoid the internal morality of law from producing of evil aims and inhuman enterprises, and, (ii) improve and enhance the external morality, of substantive aims of law. Nevertheless, Fuller sometimes treats the legal morality as the only practical efficiency that is neutral to the moral aims of law, here the internal morality of law basically has been treated by Fuller as 'practical efficiency' that leads to the morality aims of law. Here, the efficiency and morality are intertwined in Fuller's argument. All this leads to the conclusion that the external morality or substantive aim of law depends on the recognition of the internal morality of law, otherwise any substantive morality would be impossible (Fuller, 1949:97).

This way of interaction, however, seems insufficient because it provides Fullers' critics with the reason for thinking this connection is not the relationship between the two moralities of law. It is rather the connection between the law (without any special morality) and its moral aims. As long as someone should make the law, then, the aims of law are the agendas of its makers. Here the internal morality of law only treated as a mere effective of lawmaking that directs for open- ends of law whether this legal end will be a morally good or a morally evil. If the lawgiver of country $\mathrm{X}$, for example, enacts a law that allows the torture, it will be absurd to find any connection between; the internal morality of law and the external morality of law. This might even lead to disapproving Fuller's defense to the model of the internal morality of law (Priel, 2013:2013).

This claim is rather misleading. It might be correct to consider Fuller's internal morality of law as a principle of efficiency toward the realization of substantive aims of law, but the core idea of internal morality of law is possible only when the trusteeship between the lawgiver and subjects, and the interaction between subject and his fellow has been promoted within the model of internal morality of law (Murphy, 2005:68). This point also explains why Fuller colorfully emphasizes the importance of the general rule because it is not only the character that promotes the equal interaction between lawgiver and subject, but it is also the basic character that distinguishes the law from other forms of social order, especially the form of managerial direction and the office of boss (Fuller,1949:40).

The second path of connection between the two moralities of law, however, is exceptional. It is exceptional because it brings one moral value from the substantive morality of law to build in the internal morality of the law. This moral value, in our view, is human dignity. Here, the internal morality of law depends on the external morality of law. Human dignity emerges as moral material within the formulation of internal morality of law and performs an essential role in the originating of the legal system. One way to justify Fuller's appeal to human dignity within the connection between internal and external morality of law is by advancing the thesis that law is a valuable thing in the viewpoint of practical persons who engages in the law. The law is valuable because it constitutes the public condition that builds up, or roots in, the respect of human dignity. This interpretation can be drawn from Fuller's statement "[I]n an ordered system of law, formulated and administered conscientiously, a certain built-in respect for human dignity, and I think it is reasonable to suppose that this respect will tend to carry over into the substantive ends of law (Fuller,1949:665-666)". 
This passage implies that the form of law matters, in Fuller's view, because it presupposes respect of person with dignity and agency. The respect for human dignity is not a mere result of law; it is already presupposed and grounded the public condition and the form of law (Muhamad-Najm, 2019:60). On this ground, the law should be represented as public forms and general conditions that demand a mutual respect in the community of human interaction. This is by which human beings can live together in the aspiration of the conception of freedom and agency, and the respect of human dignity. Specifically, the law should be understood, as a set of institutions that create, interpret and enforce general rules of human interaction in a community that orientate toward the aspiration of respecting human dignity. Hence, the law is only meaningful activity and valuable enterprise in the viewpoint of practical person. When the foundation of law attempts to restructure the social relations and communication between human agents so that such social relations should be rendered consistent with human dignity.

\section{The Rationality of Legal Morality}

Outside Fullerian jurisprdauince, it is important to present the reason or rationality beyond seeking to the nature of connection between law and morality. Three propositions shall provide the answer to the rationality of legal morality:

P1: There is contingent nexus between law and morality

$\mathrm{P} 2$ : There is necessary nexus between law and morality

P3: There is legal practical nexus between law and morality

The P1, true here as throughout the theoretically, entails that the important connection exists between law and morality is contingently significant. It is a contingent because formulating and entering any principle or value from the morality's world into the legal world depends on the affirmation by the one who make the law. The lawmaker here includes any powerful source relates to making and applying law. This implies that the principles of morality are external to the nature of law and totally different from the law's world. Accordingly, most legal philosophers agree that it is evident that both law and morality serve to channel human behavior. Law accomplishes this primarily through the threat of power, external obligations and possible sanctions if people disobey legal rules. Morality too involves incentives; bad acts may result in guilt and disapprobation, and good acts in virtuous feelings and praise. These two very different, however, avenues of effect on our actions are examined in the context of systems: legal system and moral system. In the meantime, most legal philosophers agree that between law and morals there is a close connection, because the moral principles of good, justice and truth are appliances and promoted by the system of law, even if the right and the moral retains its identity.

This is a point well defined in Fuller's argument of external morality of law. It is external in the term of external to the nature of law and it depends on the confirmation and selecting. But what it is moral in Fullerian project to how seek for a deeper connection between the nature of law and morality. This makes a call for the second $\mathrm{P}$.

The P2 concerns that is of interest, it is not only the well and possible connection between law and moral contingently, it is further said, is whether there is some kind of necessary connection between law and morality. Here Fuller's proposal manifested in the idea of "internal morality" of law. This "internal" can be interpreted in contemporary language of legal philosophy as the conceptual or essential into the law itself; that is law has certain "necessary" or "essential" features, which distinguish legal norms from other sorts of norms (Moore, 2012:435). Among this necessary or essential or internal feature is the idea of some morality. This 
entails that if we have any idea of law conceptually stands; it could not stand without the direct and essential of including of some morality. Although Fuller is not clear about the nature of this internal morality, Fuller's proposal of internal moral of law invites us to a powerful type of morality that must include within the concept of law. For example, if we go with the view that this " internal morality" is a formulation of the value of the rule of law and respecting human dignity within the concept of law, we are beside a new morality conception of law, that is; Dignitaries or "Dignified Conception of Law" (DCL) (Waldron,2012:206-208).

According to the DCL, the law contents in it respect the condition of human dignity and echo with the form and content of law at the fundamental level. The fundamental level is about the existing conditions of law (What is law or What is the nature of law generally?) and legal systems. That is, the condition that must be satisfied in order for a system of rules (or norms) regulating affairs and human interactions to count as a legal system. At this level, the DCL entails that some of morality is part of our idea of law or legal order, so that derogation from it means a normative system is less legal and that, at a certain level, a system should not be considered as a law at all. Accordingly, for the enterprise of law to live as morally idea, it is accepted as legitimate insofar as it guarantees of some morality, that is respecting human dignity as an autonomous agency. It must guarantee the demarcating areas in which persons can exercise their free choices and plans. It also must guarantee the non-domination conditions of those subjects to the legal rules, to not live as inferiors at the mercy of power-holders. Legal enactment and applications must be such that they secure the public and equal participation of those subject to it in the following ways: (i) the legal order can be seen as issuing from the collection of citizens' rational self-legislation, so they are the original authors of law; (ii) the legal order is an argumentative and commutative idea which allows citizens with legal interests and obligations at stake to be able to speak for those interests, whether they accuse or are accused; and, (iii) citizens have to see the legal order as it generates their capacity or voice to signal their commitment to or rejection of legal order, and the stability of the system depends on that signalling. Therefore, the DCL presents the law as a morality idea that successfully governs the healthy legal system. To say that the law is not successful implies that the governance of people by those rules fails. These rules are either not the mode of governance by the rule of law, defective as law, or not the law in the full sense.

At this fundamental level, the DCL resists the view that applies a legal norm to a human individual, like deciding what to do about "a rabid animal or a dilapidated house- as thing". It rather involves paying attention to the autonomous agency of ordinary human individuals and respecting their capacity of rationality, understanding and following within a non-domination condition (Waldron,2012:222). In particular, the DCL embodies a crucial dignitaries idea through respecting the dignity of those to whom the legal norms are applied and counting them as having the "capacities for practical understanding, for self-control, for self-monitoring and modulation of their own behaviour in relation to norms that they can grasp and understand." It resists the enterprise of building a system of domination under the arbitrary power of a public or private power-holder. The society that lives under the DCL is not a slave-owning society whose slaves are no more subject to the rule of law than are animals or tools. According to the DCL, thus, the enterprise of law has a commitment to institutionalizing the recognition by all citizens of each other as autonomous agents by virtue of human dignity (Waldron, 2012:230). That commitment in and of itself imposes a structure on the way that citizens relate to each other in setting the terms of their common life and interactions. Most important of all, they must attempt to create and sustain a culture in which they try to justify to each other what they hold should be done in the name of the common good of human dignity under the rule of law (Muhamad-Najm,2009:77).

The P3 shows the practical significant connection between law and morality. Doing legal philosophy should not only to be for the sake of knowledge or theoretical exercise. It must rather have a practical task. The task of legal philosophy, as Fuller tells us before anyone, should be adjudicated by asking, "[w]ould the 
adoption of the one view or the other affect the way in which the judge, the lawyer, the law teacher, or the law student, spends his working day?" For this, Fuller is less interested in the proposal of definitions of law if they are not accompanied by the admission that definitions are "direction posts for the application of human energies", never purely descriptive, always potentially prescriptive. Accordingly, he hopes that the future legal philosophers will shift away from a descriptive model because this model would cease to be descriptive to represent legal phenomena and will turn instead into an analysis of the social processes that constitute the reality of the law. However, Fuller himself could not complete this task. He has less time to foundationally seek to the practical task of his proposal of connection of law and morality (Legal Morality) except in a very narrow application ( Fuller, 1949:889).

One can employ Fullerain legal morality, through P3, by saying that the legal morality requires that the law contents in itself respect the condition of some of morality (such as the rule of law and respecting human dignity) and echo legal morality at the doctrinal legal and judicial reasoning. This entails the conditions of legal validity and answering what is the proposition of legal rule to a particular case (What is the law or the particular rule or judicial reasoning for hard cases). In this level, for any single norm to count as among a community's law, it must conform to some legal morality.

This implies the legal morality posits a measured test for legal validity and juridical reasoning. The legal validity of any of the content of legal norms is always determined to some extent by the legal morality. This account also defines the legal and moral obligation of law-makers and judges that is manifested in the idea of fidelity to the rule of law (Allan, 2003:107). In particular, this claim affects the way that law exists in any legal culture, including the practices of judges, other officials and legal administration, and citizens. If the law-makers, for example, enact the legislation, they have to consider that legislation in correspondence to some legal morality. If judges, for example, are not interpreting legal content in the methods that give impact to some legal morality, they are not faithfully complying with their legal obligations. The legal morality then demands that some internal morality (such as the rule of law and respecting of human dignity) is the measure of a legal order to which judges must be faithful in identifying and interpreting the content of valid law (Dyzenhaus,2010:248). This is the core of P3.

From the above three Ps (P1, P2, and P3), one can put a powerful conclusion: there is always a connection between law and morality; some of this connection depends in the way that externally and intentionally by powerful holder enter the principles of morality into the law; meanwhile, there is some internally and (even essentially) of some morality that must enter into the idea of law (such the value of the rule of law and respecting of human dignity). The former connection is external and depending on the ideal and aspiration developing of the morality to the law in any society; while, the later connection is internal to the law and not need any involving.

Here is an example. If we consider the principle of human dignity (as one example of morality value); it can enter into the law in two ways: as the external principle to some legal documents, and as the internal principle into the idea of law itself. For the way, there is no doubt that such human rights' provisions and constitutional provisions are the most obvious ways that enforce the protection of human dignity (external morality to the law). The difficulty, however, begins when we face the hard cases where there is no mention of human dignity in the legal provisions, while the nature of those hard cases directly relates to the respect and protection of it. Moreover, more challenges are faced when the worst violations of human dignity take place in cases where political structures are wicked or weak because the rule of law is absent. In these cases, where the violations of human dignity occur, whether caused by public officials, powerful groups or private persons, they are so basic, so profound that theoretical discussion of what human dignity means and how it relates to the law seems utterly misplaced and confused. It sometimes could be believed that the law is the 
source of evils, including the violations of people's dignity. It is even a truism to say that more or less wellordered societies and developed systems are meant to provide a measure of protection from the most egregious violations of human dignity, through adopting a powerful provision of human rights and constitutional rights. And yet interestingly, when violations of human dignity occur in those well-ordered societies, whether under the auspices of making policy and judicial activity, they involve a very specific and sense of wrongfulness that increases the actual harm to the dignity of human individuals. If all human rights are founded on the recognition of human dignity, how do we explain it when we observe that a certain positive law violates human dignity (as a moral value)? Is it possible that the idea of law takes the blame, because its coercive traits and commands have been considered as the main feature of the law; that along with its claim to legitimate authority, it opens up the possibilities to render injury to human dignity? Furthermore, even worse, is it possible to believe that the law itself may become a profound sense and instrumental agenda of injustice when acute dissonance occurs between the legal and political authority that is exercised by the official rulers, such as law-makers, judges and police officers? Then we have the very real experience of misrecognition of standing with dignity. Thus, seeing the morality human dignity within the legal documents externally (put into the law) may provide us with a fine understanding of how law relates to the morality. It has advanced our grasp of the idea of human dignity as a legal and judicable concept, along with some of its legal implications. However, this way alone fails to provide a deeper connection between the nature of law and human dignity (morality). It falls short of explaining how the very idea of law can be possible and truly relates to the protection of a person's dignity when the rules of law operate and govern human life. Therefore, Fullerian legal morality, with some of our justification as stated above three $(\mathrm{P}) \mathrm{s}$, eventually pays our attention of why we have such an interest in the proposal of legal morality both theoretically and practically.

\section{Conclusion}

To this end, the core arguments of the study sought to answer two main questions as follows: what are the types (or forms) of connection between law and morality?, and why should care about these connections?

The first section speculated the answer to the question of the "what?" are types of the relation between law and morality in Fullerian jurisprudence, and these are; the morality of duty, the morality of aspiration, the morality of legal person, the morality of legal official, the morality of legal end, the morality of legal content, the external morality of law, and the internal morality of law. Few of these forms are well and good defined by Fuller himself. But Fuller owes us a complete and a systemic account of what he means by other types while he only mentioned to us. A part of this study attempted to clarify this point.

It is also important to seek for the question of the motivational and rational, or "Why?" question: why is theoretically as well as practically important turning to such interest thesis in legal philosophical studies, especially within Fullerian jurisprudence? The answer of why question has been answered in the light of the three propositions in the second section; that there is contingent nexus between law and morality; that there is necessary and conceptual connection between law and morality, and finally that there is judicial and practical outcome to consider the relation law and morality. Within this argument, there was also an appeal to the principle of human dignity within the thesis of legal morality. 


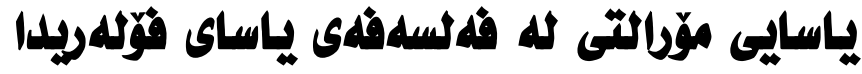

\section{هيّين ابراهيم قدادر}

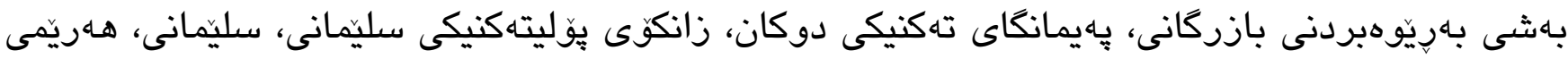
كوردستان، عيّراق.

Hemin.qadir@spu.edu.iq:ئيمهيل

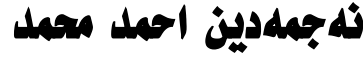

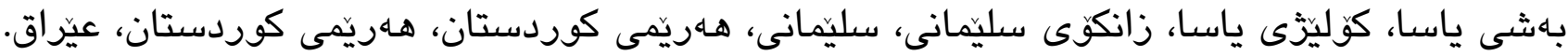
najmarchieve@gmail.com : بيمهيل

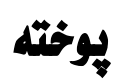

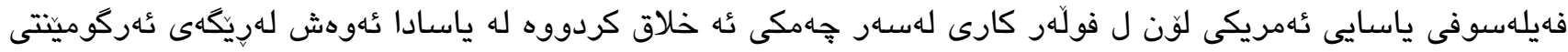
تيزهكهى لهسهر ياساى ئه خلاق. ئهو بهتايبهتى وهك ئايدياى رِومانتوسيك له " ناوهوهى ئهخلاقى سياسى" كارى كردووه به جوّرىي

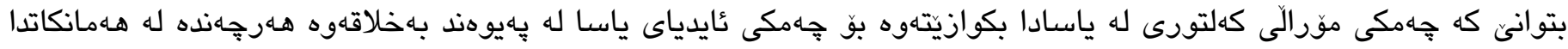

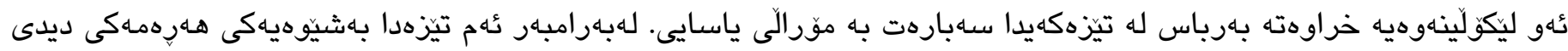

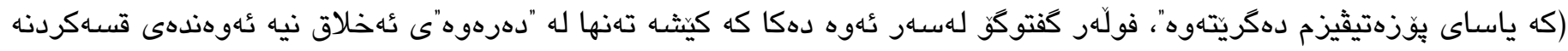

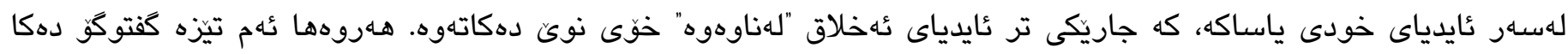

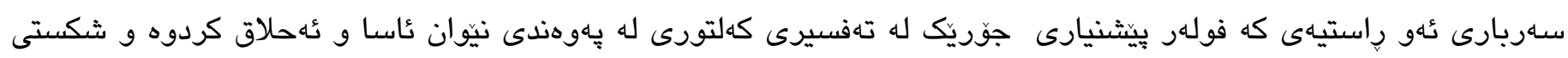

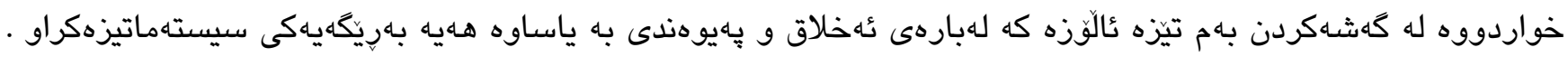

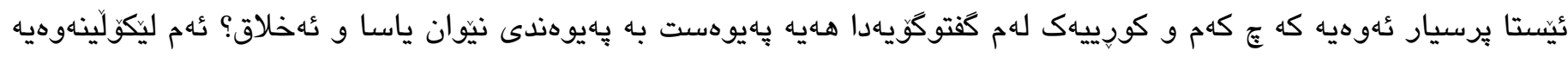

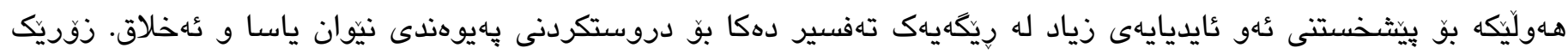

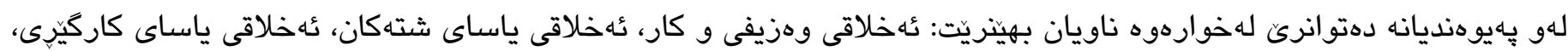

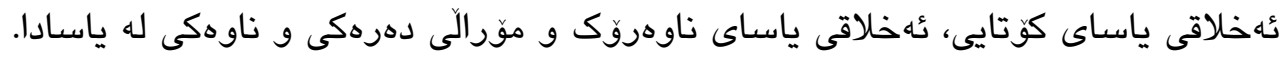

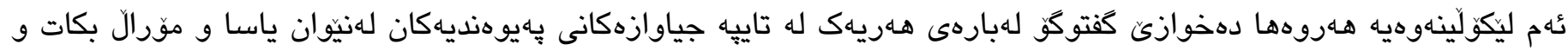

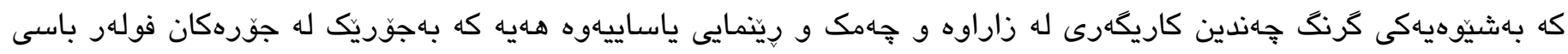

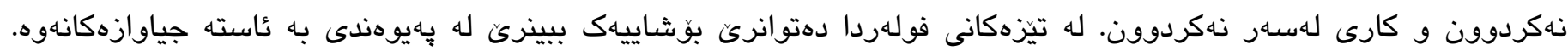

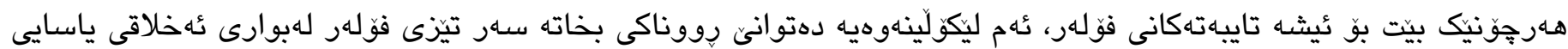

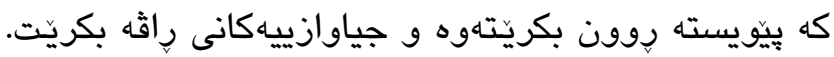

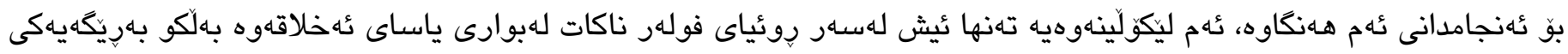

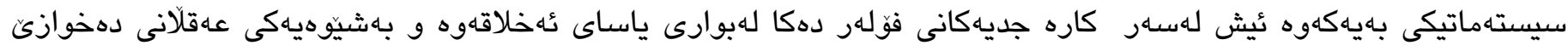
لايهنه شاراوهكانى ياساى ئهخلاق راثه بكات. بـاتهن.

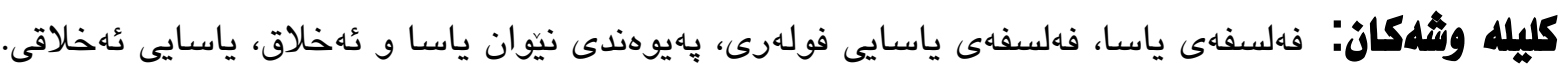




\section{Refreense:}

Allan . T.R.S (2003). Constitutional Justice.2 $2^{\text {nd }}$ edn. (Oxford University Press).

Barzun, Charles (2018). “Three Forms of Legal Pragmatism”, $1^{\text {st }}$ edn. 95 Washington University Law Review $5,1005$.

Bennett, Mark (2011). "Hart and Raz on the Non-Instrumental Moral Value of the Rule of Law: Reconsideration” 30 Law and Philosophy 603, 607.

Bennett Mark, (2007). “The Rule of Law' Means Literally What it Says: The Rule of the Law': Fullerand Raz on Formal Legality and the Concept of Law” 32 Australian Journal of Legal Philosophy 90 Coyle, Sean (2014).Modern Jurisprudence: A Philosophical Guide. $1^{\text {st }}$ edn. (Hart Publishing,).

David, Dyzenhaus (2006). The Constitution of Law: Legality in a Time of Emergency. $2^{\text {nd }}$ edn. (Cambridge University Press, Cambridge).

David, Dyzenhaus (2010).Hard Cases in Wicked Legal Systems: Pathologies of Legality (2nd ed., Oxford University Press,).

Fuller,Lon.L (1958). "Positivism and Fidelity Law-A Reply to Professor Hart”, 71 Harvard Law Review $630,659$.

Fuller,Lon.L (1954). “American Legal Philosophy at Mid-Century’, 6 Journal Legal Education 457

Fuller,Lon.L (1969). “Human Interaction and the Law”, 14 American Journal of Jurisprudence 1

Fuller,Lon.L (1975). "Law as an Instrument of Social Control and Law as a Facilitation of Human Interaction”, 1 Brigham Young University Law Review 8.

Fuller ,Lon.L (1958). "Positivism and Fidelity to Law - A Reply to Professor Hart”, 71 Harvard Law Review 630

Fuller, Lon.L( 1940). The Law in Quest of Itself. $2^{\text {nd }}$ edn (Chicago: The Foundation Press,)

Fuller, Lon.L (1969).The Morality of Law (revised edition), (New Haven: Yale University Press,)

Haack \& Robert, (2006). Pragmatism, Old and New (New York, Prometheus Books,)

Halpin, Andrew (2006). "The Methodology of Jurisprudence: Thirty Years Off the Point”, 19 Canadian Journal Law and Jurisprudence.

Hart, H.L.A (1958). "Positivism and the Separation of Law and Morals", 71 Harvard LawReview .

Hart, H.L.A (1994).The Concept of Law, (second edition) (Oxford: Oxford University Press,

Luban, ,David (2007).Legal Ethics and Human Dignity (Cambridge: Cambridge University Press)

Muhamad, Najmadeen Ahmed (Najm) (2019).The Legality of Human Dignity, Developing the Legal Philosophy of Lon L. Fuller (PhD. Dissertation, University of Birmingham, School of Law, UK,) (unpublished). 
Muhamad, Najmadeen Ahmed (Najm) (2019). The Immorality of Legality inside Saddam Hussian's Rule of Law (Unpublished paper).

Muhamad, Najmadeen Ahmed (Najm) (2021), The Legal Philosophy of Lon L. Fuller: Profile, Social Contract Journal (forthcoming first issue).

Murphy, Colleen (2005) . "Lon Fuller and the Moral Value of the Rule of Law", 24 Law and Philosophy 239

Nadler, Jineffer (2007). "Fuller, and the Connection Between Law and Justice", $27 \quad$ Law $\quad$ and Philosophy 1

Priel,Dan (2013). 'Reconstructing Fuller's Argument against Legal Positivism Reconstructing Fuller's Argument against Legal Positivism', 26 Canadian Journal of Law \& Jurisprudence 399.

Rundle, (2009). "The Impossibility of an Exterminatory Legality: Law and the Holocaust", 59 University of Toronto Law Journal 65

Rundle, (2012).Forms Liberate: Reclaiming the Jurisprudence of Lon L Fuller (Hart Publishing,).

Soosay, (2011). "Rediscovering Fuller and Llewellyn Law as Custom and Process" in Maksymilian Del Mar (ed.) New Waves in Philosophy of Law (Palgrave Macmillan, )

Waldron, (2008).'Positivism and Legality: Hart's Equivocal Response to Fuller' 83 New York Law Review 1152.

Waldron, Jeremy, (2008). "The Concept and the Rule of Law”, 43 Georgia Law Review

Waldron, Jeremy, 'How Law Protects Dignity' (2012) 71 Cambridge Law Journal,

Winston, ( 2001).The Principles of Social Order - Selected Essays of Lon L. Fuller, (revised edition)

(Portland: Hart Publishing,)

Witteveen, Willem J. and van der Burg, Wibren (eds), Rediscovering Fuller: Essays on Implicit Law and Institutional Design (Amsterdam: Amsterdam University Press,)

Moore, (2012). 'The Various Relations between Law and Morality in Contemporary Legal Philosophy' 25 Ratio Juris 435

Patterson, (2012) . Necessity in Law and Morals, 25 Ratio Juris 1. 